\section{Liber Meus. Pēterim Upītim 120}

Atslēgvārdi: Latvijas grafikas vēsture, ekslibris grāmatzīme, Pēteris Upītis, grafikas augstspiedes tehnikas.

Pētījumā iezīmētas divas dạ̣as - pirmā veltìta ekslibrim jeb grāmatzīmei, kas Latvijā piedzīvoja savus uzplaukuma gadus 20. gadsimta otrajā pusē, un otrā daḷa veltīta vienam no izcilākajiem šì grafikas žanra meistariem - Pēterim Upītim (1899-1989). (1) 2019. gadā atzīmējām P. Upī̌̌a 120. gadadienu, bet pirmā mākslinieciskā grāmatzīme Latvijā tapusi 1897. gadā tātad divus gadus pirms viņa dzimšanas dienas. Tā ir grāmatzīme, ko Evai Sundblādei litogrāfijas tehnikā darinājis grafiķis Rihards Zariņš.

Zīme grāmatā - grāmatzīme - ir ne tikai īpašs mākslas darbs, tas ir arī stāsts par lasītāju, par viņa gaumi, interesēm un vājībām. Mākslinieks šajā simbolā ir kā starpnieks, kuram nepieciešama vērīga acs, ass prāts un loti augsta meistarība. Ekslibris jeb grāmatzīme ir kā piederības apliecinājums, īpašnieka zīmogs, personības simbols, kurš ir ietilpīgs un kura nozīme ir telpiski daudzslān,aina. Ekslibris ir īpašs arī tādēḷ, ka tas ir miniatūrdarbs, ko parasti veido kādā no grafikas oriǵināltehnikām, īpaši ksilogrāfijā, no kuras klišejas var iegūt lielu skaitu novilkumu. Šāds mākslas darbs no mākslinieka prasa ārkārtīgu meistarību, virtuozitāti un spēju koncentrēti mazā formā pateikt svarīgāko. Ekslibru māksla ir īpaša, tai nepieciešama l,oti lakoniska, precīza forma un saprotams vēstījums, lai gan arī bieži - simboliski vispārināts saturs. Tas ir grafikas dizaina meistardarbs.

\section{Īpašuma piederības zīme}

Īpašuma piederības zīmes ir senas kā pasaule. Tās atrodam gan Ēǵiptē, gan Asīrijā. Cilvēki arvien ir vēlējušies savas lietas iezīmēt. Arī visas ražotāju un izgatavotāju zīmes, ko mūsdienās saucam par logo, faktiski ir īpašuma zīmes. No vissenākajiem laikiem ir saglabājušās dažādas lietas, kuru izcelsmi un piederību varam noteikt pēc īpašām zīmēm. Ilgu laiku par tādām kalpoja ǵerboṇi - gan pilsētu, gan dzimtu. Pateicoties tām, daudzas lietas pašlaik var atgriezties sākotnējā kolekcijā. İpašuma zīmes tika liktas uz traukiem, mēbelēm, un pat apgèerbu rotājumā kā organiska sastāvdaḷa tika izmantoti iniciāli - monogrammas.

Vēl arvien kā īpašas, īpašniekam noteikti atgriežamas ir grāmatas. Vērtīgākās no tām iezīmējam ar kādu īpašuma zīmi - kaut vai tikai ierakstām savu vārdu. Grāmatas ir kaut kas ḷoti īpašs, tām ir speciāla vieta istabā, tās ir sarindotas pēc noteiktas, īpašniekam vien zināmas kārtības. Atverot grāmata mūs it kā ielaiž pa durvīm, bet aizverot tajā paliek dalinna no mums. Tās ir l̦oti intīmas attiecības, īpašas tādēḷ, ka nav izstāstāmas. Izcilais krievu mākslinieks Vladimirs Favorskis (Владимup Фаворский; 1886-1964) savos teorētiskajos darbos par grafiku un grāmatu mākslu salīdzina grāmatu ar arhitektūru - celtni, kuras ārējā redzamā vai tehniskā funkcija ir dzīvesvietas radīšana. Savukārt grāmatai tāda funkcija ir zināšanu ieguve. Bet salīdzinot redzam, ka abām ir vēl otra, varbūt pat svarīgāka funkcija - tā ilgst telpā un laikā. Tā var mainīties, 
tās attīstību stimulē neatnemamā, klātesošā tehniskā funkcija. Grāmata ir kā pasaule - īpaša un vienreizēja, tāpat kā māja. Un katrai mājai ir saimnieks, katrai ir numurs, plāksnīte ar īpašnieka vārdu. Viņš atbild par visu, kas ar māju notiek. Uzraksts - privātīpašums - liek mums izturēties ar bijību.

Arī grāmata ir privātīpašums. Grāmatu telpiskums un laikietilpība noteikti spēj ietvert lasītāju dzīves daḷinu. Tāpēc arī bibliotēkās atmosfēra ir tik mainīga, savāda un ne visiem paciešama. Tieši bibliotēku veidotāji arī bija senāko grāmatzīmju pasūtītāji, grāmatzīme jau esot bijusi Ninives valdniekam Ašurbanipalam 7. gadsimtā pirms Kristus. Zīmes un ierakstus grāmatās pat tiesa atzina par pietiekošu īpašuma pierādījumu. Dažādu ierakstu esamība, kaut arī sena, tomēr ir tikai pieñēmums, ka tieši tādā veidā ir radusies tradīcija lietot ekslibri.

Ekslibris tomēr nav tikai īpašuma zīme. To drīzāk var nosaukt par īpašnieka simbolu - zìmi, kura ir ietilpīga un kuras nozīme ir telpiski daudzslān,aina. Tā stāsta par grāmatas saimnieku visu - gan to, kas ārēji redzams un viegli nolasāms svešajam, gan arī to ìpašo un noslēpumaino, kas atpazīstams tikai tam, kas labi pazīst adresātu un zina pat to, ko paši īpašnieki par sevi nezina. Tāpēc labu - patiesi atbilstošu un l,oti piemērotu - ekslibri var izgatavot tikai pazīstamam cilvēkam. Lieliskākās ir tieši tās zīmes, kas pilnīgā veidā, kā simbols mums atklāj īpašnieka vājības un paradumus. Šādā uzdevumā apvienojas gan psihologa un novērotāja spējas, gan kolosāls mākslinieka talants. Tādās zīmēs mēs nejūtam disonansi starp amata meistarību un attēloto objektu. Mēs vispār nejūtam to, kā tā ir darināta. Nav svarīgi, vai tas ir augstspiedums vai dobspiedums, kokgrebums vai kokdzelums, ekslibris visu sintezē unikālā veidā, un neredzamais kḷūst par redzamo. Būtisks temata pamatojums ir fakts, ka latviešu mākslinieku vecākās paaudzes ieguldījumu mākslinieciskās grāmatzīmes izveidošanā un attīstībā ir pētījis un aprakstījis tieši Pēteris Upītis, akcentējot un izceḷot trīs autorus - Rihardu Zarinu (1869-1939), Sigismundu Vidbergu (1890-1970) un Niklāvu Strunki

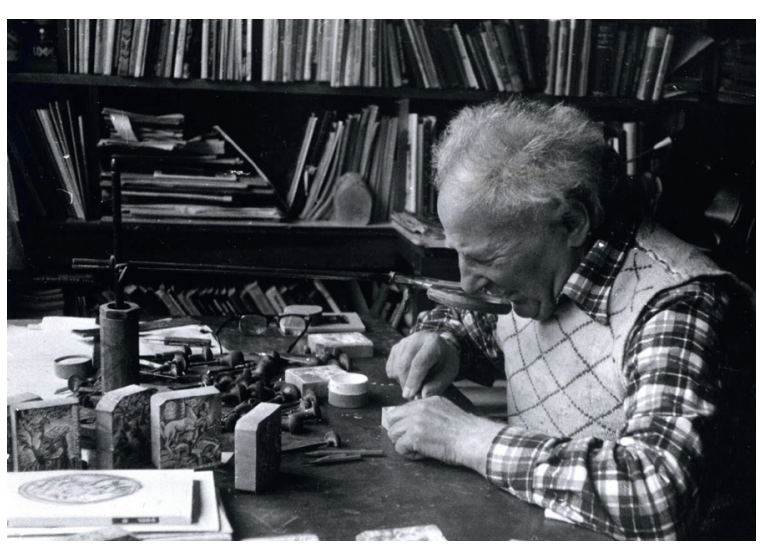

Pēteris Upītis, 1984. gads. Foto no K. Upīša kolekcijas

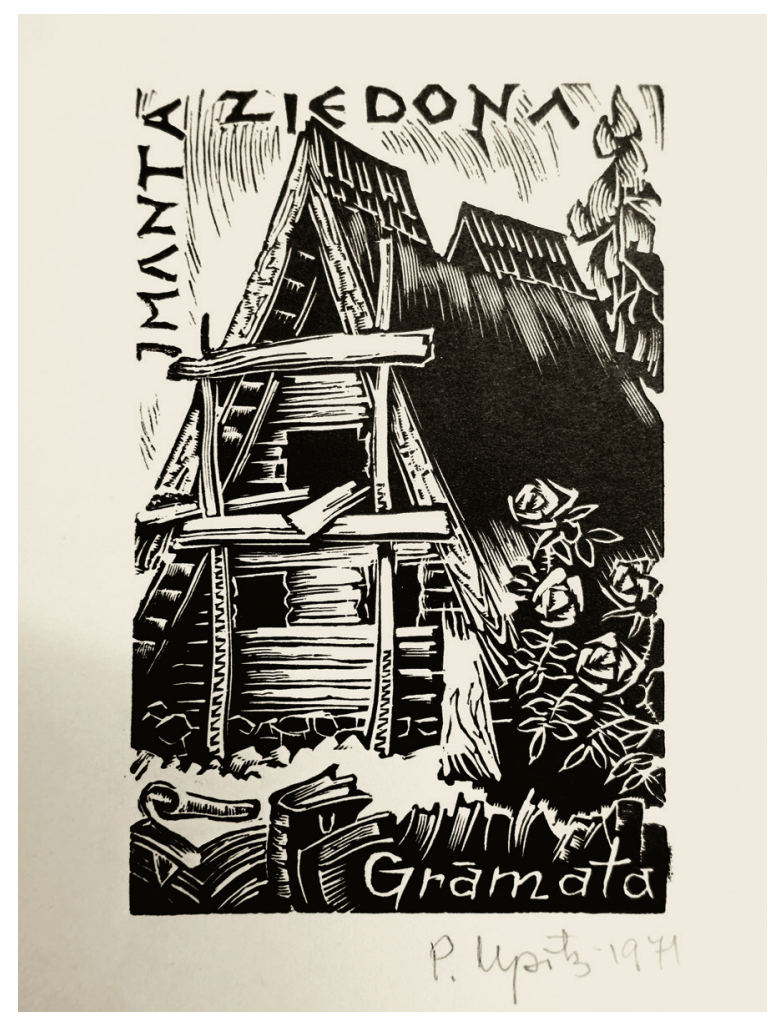

Imanta Ziedoṇa grāmata. 1971. Ksilogrāfija. Op. 204 
(1894-1966). Viņš sniedzis kopumā plašu vēsturisku ieskatu šajā tematā. ${ }^{1}$

Mākslinieciskā grāmatzīme ir kā biogrāfija. Talantīga mākslinieka rokā top zīme, kurā redzam vizuālas, simboliskas atsauces uz adresāta izglītību, mīlestību un vaḷaspriekiem. Tāda zīme, kas ielīmēta priekšlapā, ir kā pierādījums grāmatas kvalitātei. Kaut tās ir pavisam miniatūras, tām ir sava klasifikācija. Tās var iedalīt heraldiskajās, sižetiskajās un tā sauktajās šrifta grāmatzīmēs. Ar šo dalīšanu gan nodarbojas nevis mākslinieki vai lasītāji, bet gan tikai kolekcionāri, kuri apvienojušies starptautiskā organizācijā Federation Internationale des Societes d'Amateurs d'Exlibris (FISAE), ko nodibināja 14 ekslibra biedrības 1966. gadā XI kongresa laikā Hamburgā. Federācija ir kḷuvusi par oficiālu UNESCO organizāciju, kurā var iestāties nevis privātpersonas, bet tikai atsevišķ vu valstu biedrības. Jau ilgi pirms tam, 1953. gadā, Austrijā notika pirmais kongress, kurā piedalījās aptuveni 60 cilvēki no septinām valstīm. Šobrīd FISAE apvieno 43 ekslibra biedrības, nodarbojas ar koordinācijas jautājumiem, palīdz uzturēt kontaktus starp dažādu valstu māksliniekiem un kolekcionāriem. Biedrība, kas vienlaicīgi apvieno gan tos, kas krāj un kolekcionē, gan tos, kas izgatavo šos miniatūrgrafikas darbus, škiet, ir visai unikāla tieši šî iemesla dēḷ. Īpaši nozīmīgs šādu apvienību vēsturē bija 1891. gads, kad gandrīz vienlaicīgi vairākās valstīs tika dibinātas īpašas ekslibra interesentu biedrības. Pirmās gods tomēr pieder Londonā dibinātajai, kurā varēja darboties jebkurš gribētājs no visas pasaules. Jau pirmajā gadā sāka iznākt specializēts žurnāls ("Journal of the Exlibris Society") un vairāki simti mākslinieku un kolekcionāru kḷuva par šīs biedrības aktīvistiem.

Kopš šì senā laika l,oti daudz kas ir mainījies. Agrāk kolekcionāri galvenokārt nodarbojās ar senu mākslas darbu kolekcionēšanu, bet tagad ir notikusi loti specifiska interešu

1 Upītis, P. 1958. Pirmās latviešu mākslinieciskās grāmatzīmes. No: Latviešu tēlotāja māksla. Rīga: Latvijas Valsts izdevniecība, 307.-325. lpp. diferenciācija - tie izvēlas savu konkrētu tēmu: citam tie ir kak,i, citam zirgi, citam bibliotēkas, rakstnieki, sievietes vai erotika. Visai populāras ir augstdzimušo personu heraldiskās grāmatzīmes. Kolekcijas specializācija var būt l̦oti šaura, tāpēc, lai to papildinātu, jānodarbojas l,oti aktīvi arī ar mākslas darbu apmain,u, kurai regulārajos kongresos tiek atvēlēts speciāls laiks. Interesanti, ka ir izstrādāti arī kolekciju apjoma standarti: ja kolekcijā ir mazāk nekā 40000 vienību - tā skaitās neliela, bet, lai tā drīkstētu saukties par lielu kolekciju, tajā jābūt vairāk nekā 80000 vienību.

Tieši kolekcionāri kultivē un uztur šo mākslas veidu, jo diemžēl nevar savas kolekcijas lietot tām atbilstošā kārtībā. Lìdz ar to zūd pati grāmatzīmes būtība - šo likteņa skarbumu var labāk saprast, ja to atkal salīdzinām kā iepriekš ar māju - tā ir kā mājas numura plāksnīte bez mājas...

Kā jebkurā mākslas darbā autors neizbēgami atklāj daḷu no sevis, tā arī, darinot grāmatzīmi, neizbēgami parādās mākslinieka pasaules redzējums.

"Pēterim Upītim 80-ajā jubilejā

Jūs esat mēra etalons

tai ainavai, kas aiziet.

Jo dēlītis - tas tikai koks, Ko jūs ar kaltu graiziet.

Bet dēlī iegriež pakalnus ar ozoliem; ar sirdi, un reizēm tajos milži dus un stārķus skaidri dzirdi, vai atkal - zīles kaut kur krīt, tā krīt, ka - Dieva zemìt, kur kāju likt, kur soli mīt, kā zīlei virsū nemīt?!

Ak, vēl būs elle un būs sērs. Un lauki būs! Un - maize! Jūs esat vecais paraugmērs tai ainavai, kas aiziet.

Cienā, lepnumā un simpātijās Imants Ziedonis, 1979. gadā"2

2009. gada oktobrī Rīgas vēstures un kuǵniecības muzeja kolonnu zālē bija skatāma P. Upītim veltīta pieminas izstāde "Aizejošā 
ainava". To bija sarīkojuši kuplās Upīša dzimtas pārstāvji, bet īpašs paldies jāsaka mākslinieka meitai Ainai Zandersonei un mazdēlam Kasparam Upītim. Izstādes atklāšanā netika teiktas pacilājošas oficiālas runas - viss bija kā mājās. Kaspara sarūpētie video, kuros varēja redzēt P. Upīti viņa ikdienas gaitās, dzirdēt viņa balsi, sajust viņa klātbūtni, sanākušo publiku, šķiet, atgrieza tajos tālajos gados, kad par brīvu Latviju tikai sapņojām, bet dzimtenes daba bija ne tikai mežu ieguves teritorija, bet arī patriotisma simbols un bezgalīgs iedvesmas avots. Arī izstādes nosaukumā radinieki gribēja ielikt šo domu: aizejošā ainava, kādu to redzam grafiķa darbos, tāda nebūs vairs nekad. Vēsturiski romantiska, aizejoša (gan tiešā, gan pārnestā nozīmē) Latvijas daba atklājās arī izstādītajos Upīša darbos īpaši izceḷot 50. gadu dail̦rades posmu, kurā, škiet, bija sasniegta radošā gara virsotne.

Uz atklāšanu bija ieradusies uzticīgākā P. Upīša studente Elita Viliama un, īpaši izcelot mākslinieka devumu ekslibra jomā, teica sirsnīgus vārdus. (3) Neparastu dzīvību un klātesamības sajūtu radīja Dzidras Ezergailes apsveikuma vārdi - vina nolasīja fragmentus no savas pēdējās sarunas ar kolēgi. (4) Tam ir īpaša vērtība, jo Dzidra Ezergaile P. Upītim ir darinājusi gandrīz simts grāmatzīmes. Izstādes atklāšanā pāris stundas pārvērtās veselā ceḷojumā laikā; atmiņas, iespaidi, skumjas un prieks tas viss vijās kopā un, skanot mazmazmeitas spēlētajai vijolei, aizveda ikvienu tajā pasaulē, kurā dzīvoja un strādāja Latvijas grafikas vecmeistars.

Pēteris Upītis ir izcils Latvijas grafikas meistars, kura ieguldījuma rūpīgu izpēti esam meistaram parādā. Plašāku monogrāfiju ir sarakstījusi Genoveva Tidomane $(1975)^{3}$, daiḷradi raksturojis Mikelis Ivanovs $(1961)^{4}$, bet rūpīgu
3 Tidomane, G. 1975. Pēteris Upītis. Rīga: Liesma.

4 Ivanovs, M. 1961. Pēteris Upītis: grafikas reprodukciju albums. Rīga: Latvijas Valsts izdevniecība.

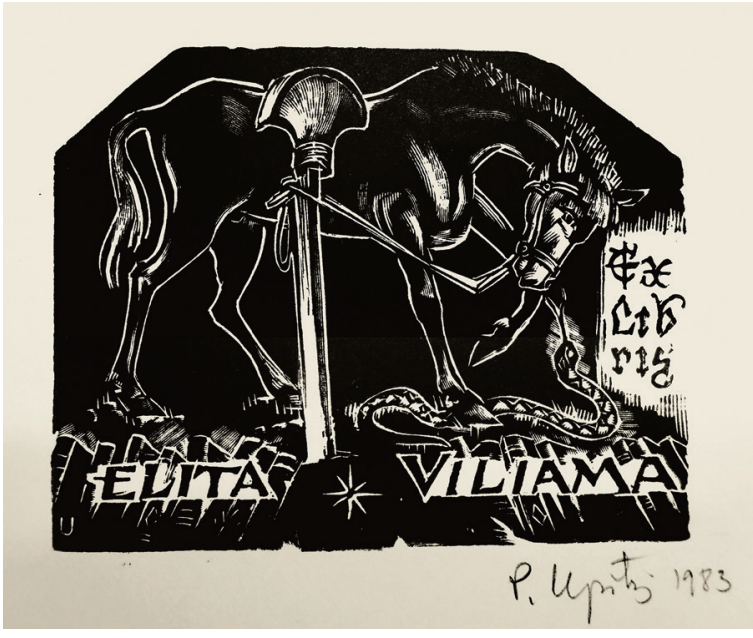

Elita Viliama. 1983. Ksilogrāfija. Op. 635

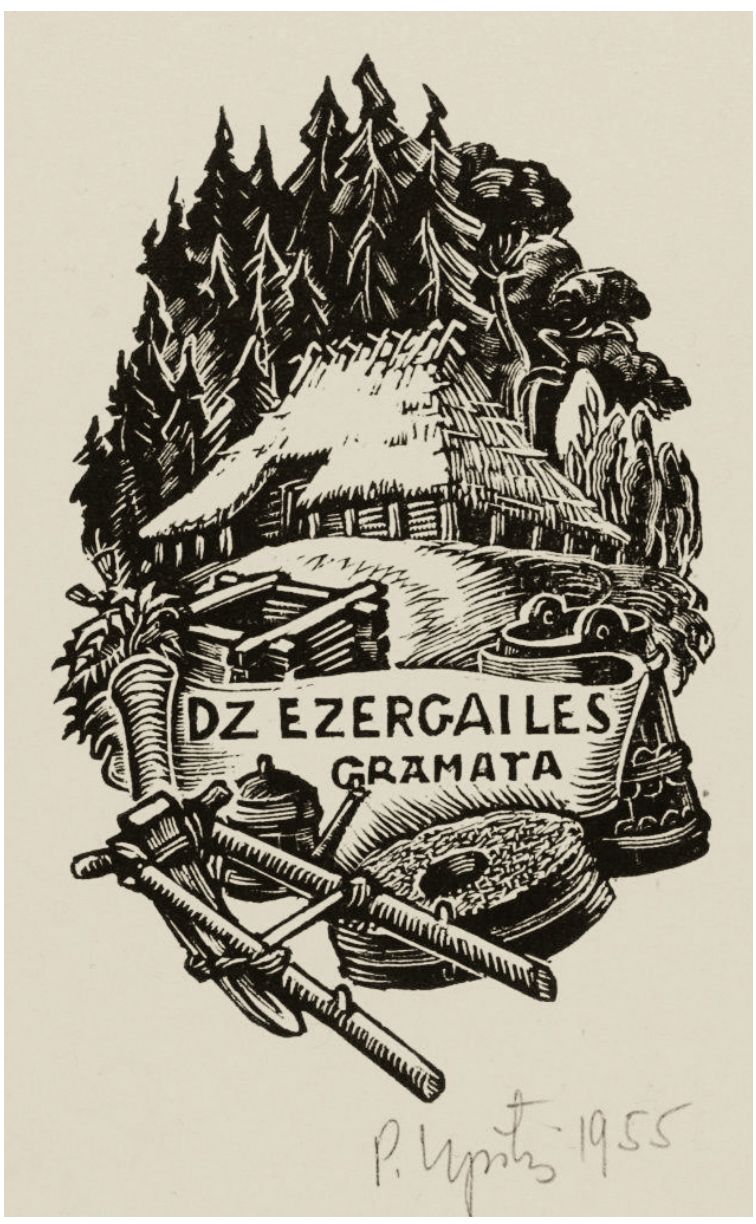

Dzidras Ezergailes grāmata. $79 \times 50 \mathrm{~mm}$. 1955. Kokdzelums. Op. 11 
un neatkārtojamu viņa grafisko rokrakstu raksturojis Jānis Siliņš (1993) ${ }^{5}$.

Ar lielu atbildības sajūtu P. Upītis attīstīja savus Dieva dotos talantus. Grafikia un pedagoga darbs bija arī viṇa dzīve, bet visu vienojošais moto - mīlestība pret mākslu. Sākot no 1945. gada un vairāk nekā pusgadsimtu viņš bija aktīvs Latvijas Mākslas akadēmijas darbinieks - kā dekāns, atbildīgi veicot administratīvā darba grūtos pienākumus, un kā profesors, savā akadēmiskajā darbībā mācot un iedvesmojot studentus. Abas šìs jomas nav atdalāmas, jo viena otru papildina, veido ideālu kontekstu kā paraugu ikvienam, kas to meklē. Aizrautīgs, neatlaidīgs, mērk̦tiecīgs - tādu studenti atceras P. Upīti. Personības spēks, amata prasme, vēstures zināšanas, pieredze - tās ir bagātības, kuras neizsīkst un kuras P. Upītis dalīja saviem studentiem. Starp vina studentiem minami tādi ievērojami Latvijas grafiḳi kā, piemēram, Zigurds Zuze (1929-2003) un Dainis Rožkalns (1928-2018), bērnu grāmatu ilustratore Anita Paegle (1956). Pateicoties viņa aktivitātei un entuziasmam, Latvijā 20. gadsimta otrajā pusē aktīvi strādāja vesela grāmatzīmju meistaru skola - Dzidra Ezergaile (1926-2013), Gunārs Krollis (1932), Inārs Helmūts (1934), Elita Viliama (1954) un daudzi citi.

Par neatņemamu pedagoga darba dalı Pēteris Upītis uzskatīja arī mērḳtiecīgu pētniecību, viņam piederēja plaša bibliotēka, viņš kolekcionēja grāmatzīmes (kolekcijā bija vairāk nekā 20000 šo unikālo miniatūrgrafikas darbu), viņš ne tikai vāca monogrāfiskus materiālus par Teodoru Ūderu (1868-1915), Jāni Plēpi (1909-1947) un par savu skolotāju Rihardu Zarinuu, bet arī cītīgi sekoja līdzi visam aktuālajam. Neatņemama viṇa dzīves sastāvdaḷa bija arī neatlaidīga Latvijas mākslas vēstures interesantāko lappušu un mākslinieka amata popularizēšana, īpaši 60 . un 70 . gados $P$. Upītis bija simtiem tikšanos dalībnieks, viņš nekad

5 Siliň̦̌, J. 1993. Latvijas māksla, 1915-1940. III $d$. Stokholma: Daugava. neatteicās no sarunām par mākslu, arvien bija gatavs lasīt referātus un dalīties ar savām unikālajām, plašajām zināšanām un pieredzi, pārsteidzot daudzus ar savu unikālo atmiṇu. Kādā audiomateriālā viṇš stāsta par 1943. gada vasaru, kad desmit dienas pavadītas Piebalgā. Vākti materiāli ilustrācijām Antona Austriṇa (1884-1934) bērnības atmin̄ām "Puiškans", kas kara apstākḷu dēḷ tā arī palika neizdotas. Kādā dienā viņš esot aizgājis līdz "Skalbītēm" (Kārḷa Skalbes (1879-1945) mājām "Saulrieti”), un pievakarē abi, sēžot pirtiņas priekšā, vērojuši saulrietu. Skalbe teicis: šodien ir atnākusi vasara... Tas bijis 23. jūlijs. Tā Piebalgā mēdz notikt arī tagad - pēc astoņ,esmit gadiem.

Kā grafikiis Pēteris Upītis bija izvēlējies visgrūtāko augstspieduma tehniku - kokdzelumu. Mākslas zinātnieks Jānis Siliņš (1896-1991) apraksta iespējamos iemeslus šādas grūtas tehnikas izvēlei un, komentējot arī citus viedokḷus, raksta, ka "kokdzelumus Upītis sācis izstādīt tikai sākot ar 1939. g., sākot tos darināt 1938. g."6. Autors izcel, apgāda "Zelta Ābele" nozīmi kokdzeluma popularitātē un raksta: “Īsta kustība Latvijas jaunajā ksilogrāfijā sākās, nodibinoties grafiķu pudurim, kam šĩ nozare kḷuva par mērkstiecīgu galveno uzdevumu."7 Šeit domāta Rīgas Grafiksu biedrība, kurai piederīgi bija kokgriezēji Aleksandrs Birzenieks (1893-1980), Izaks Frīdlenders (1890-1968), Jurijs Rikovskis (1893-1937) un Aleksandrs Štrombergs (1892-1956). Pēteris Upītis savos teorētiskajos darbos kā vienu no iemesliem ksilogrāfijas uzplaukumam min Jāņa Akuratera grāmatas "Kalpa zēna vasara" iznākšanu 1936. gadā. Tajā bija Jān,a Plēpja "gravējumi kokā". ".. tas bija vesels notikums mūsu grafikas laukā, ksilogrāfijas uzplaukuma sākums [..] Plēpis nāca klajā ar savām ilustrācijām, kam piemita vēl nekur līdz šim neredzēts izteiksmīgs vienkāršojums, atjautīga apdare, spraiga un 
ritmiska kustība, labs krāsu plankumu izkārtojums, īsts māksliniecisks vēriens."

Cietā kokā, pretškiedrā grieztie galdini (kā tos sauc paši grafiķi) jeb klišeja ir šo darbu oriǵināli. Katrs no tiem - dzīvības avots mākslas darbam. ${ }^{9}$ Katrs no tiem - vesels stāsts. Tajos kā dienasgrāmatā rūpīgi analizēts viss redzētais, domātais un meistaram svarīgais. Novilkumus jeb estampus, kas atklāj galdiṇos ieslēgtos noslēpumus, padara tos acij tīkamus un izstādīšanai piemērotus, nosacīti varam iedalīt divās lielās grupās: tās ir ainavas, kurās fiksēts un radoši atveidots Latvijas dabas tēls, un grāmatzīmes, kurās meistars atklāj savu attieksmi pret cilvēkiem, demonstrē spēju asi un simboliski precīzi atklāt katra personību. (5) (6) Neskatoties uz nelielajiem estampu izmēriem - formātu garākā mala tikai nereti pārsniedz 30 centimetrus, bet mazākajos darbos îsākā mala reizēm ir tikai 3,5 centimetri, grafiku kompozīcija arvien atstāj monumentālu iespaidu. To rada gan kokgrebuma tehnikas īpatnība, kur galvenais izteiksmes līdzeklis ir melnbalti, lineāri ekspresīvi, ritmiskās grupās kārtoti laukumi, gan arī perspektīvas lietojums, kur horizonts arvien ir augstu un sižets aplūkojams gluži kā renesanses darbos - it kā no putna lidojuma.

Viens no grūtākajiem uzdevumiem jebkurā estampa grafikas tehnikā ir drošs, veikls un precīzs štrihs, ko Pēteris Upītis apgūst, mācoties Latvijas Mākslas akadēmijā Riharda Zarina grafikas meistardarbnīcā, un pārliecinošs spoguḷattēla izmantojums, kas nereti ietekmē vienotas kompozīcijas izveidi. Arī šajā ziṇā P. Upītis ir pierādījis virtuozitāti, kura ir samērojama ar vācu renesanses lielmeistara Albrehta Dīrera (Albrecht Dürer; 1471-1528) kokgriezumiem (jo viņš pirmais savos estampos ne tikai izcēla attēlojamā siluetu, bet arī panāca koptēla tonālu daudzveidību un štrihojuma atbilstību tēla formai) un krievu skolas talantīgā grāmatu

8 Upītis, P. 1960. Jānis Eduards Plēpis. No: Latviešu tēlotāja māksla. Rīga: Latvijas Valsts izdevniecība, 332. lpp.

9 Tidomane, G. 1975. Pēteris Upītis, 67. lpp.

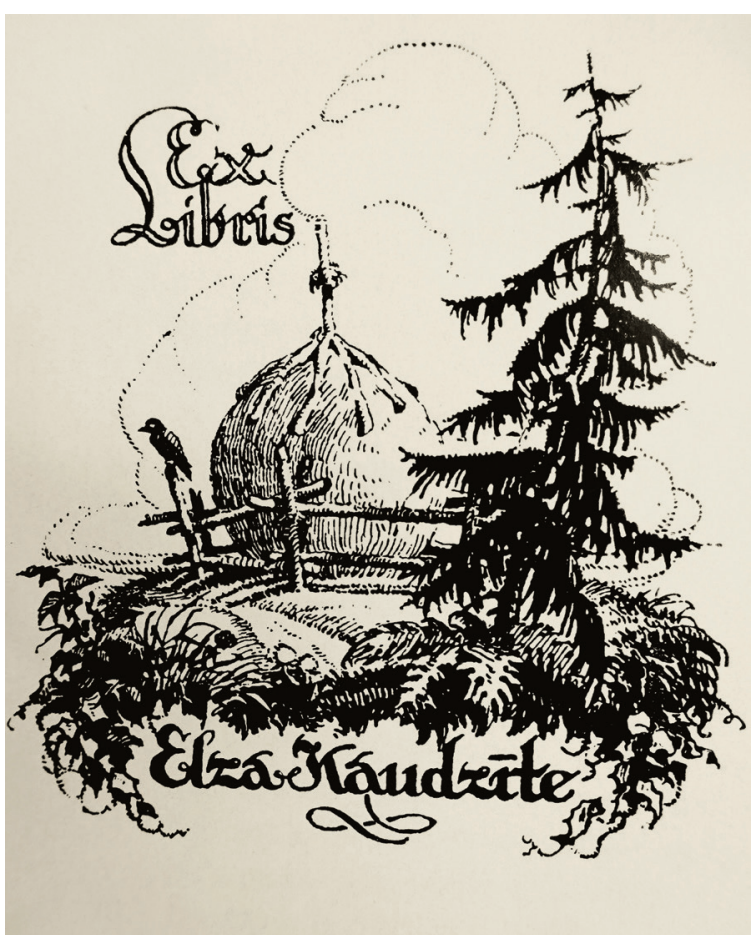

5 Elza Kaudzīte. $74 \times 61$ mm. 1927. Litogrāfija. Op. 1

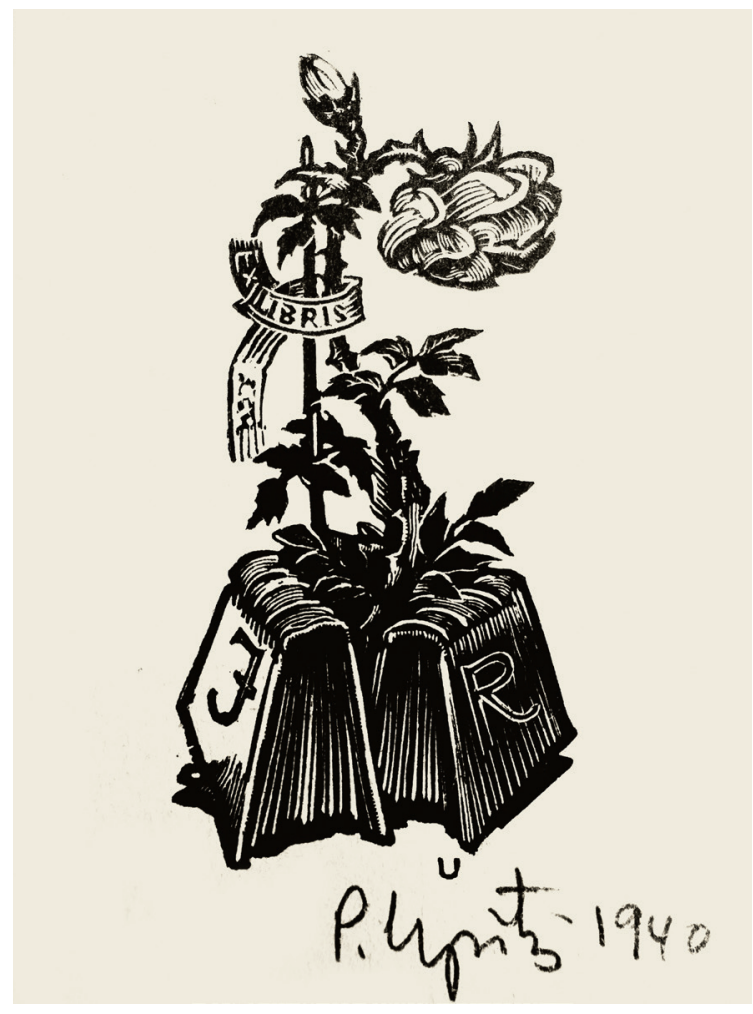

J. R. (Jānis Roze). $1940.71 \times 35$ mm. Ksilogrāfija. Op. 10 
grafiķa Vladimira Favorska unikālajiem miniatūrdarbiem. No pieminētajiem P. Upīša darbi ieguvuši kvalitāti, kas ir unikāla melnbaltām grafikas lapām, - tās atšķiras ar citu kolorītu. Tas ir tikai Latvijai raksturīgs. Daudz ir rakstīts par to, cik krāsainas nereti škiet melnbaltās grafikas lapas - Upīša darbos ne tikai redzam tumšos mežus, zeltainās pḷavas, baltos mākoņus, bet arī jūtam smaržas - zāles, ezera un sēņu - un dažreiz dzirdam pat skaņas: kā vējš šūpo koku galotnes, kā dzied putni, čalo strauts. Nāk prātā Alfrēda Kalniņa (1879-1951) dziesmas "Brīnos es, kad rudens diena..." melodija - skumja, apcerīga, ziemeḷnieciski atturīga. Grafikas lapās tādu sajūtu bagātību rada rūpīgs, neatlaidīgs meklējumu cel̦š, kur nereti top daudzas variācijas par it kā vienu tēmu.

Savās atmin̄ās Pēteris Upītis stāsta: “.. ik gadu uz saviem Čočuriem braucu vismaz divas, trīs reizes. Tās takas, birztalas, purvinini, pakalni un birztalas - tās piepilda manus sirds nostūrīšus, tās visu laiku nāk man līdzi, jo skaistāk nav nekur uz pasaules. Tur es esmu savā vidē, savā elementā. Bez skicēm nekad neatgriežos, skices ir svarīgas, tas ir kā iemūžinot to sajūtu. Īpaši man patìk pievakares, kad garas ēnas. Es neko nepārnesu burtiski, atḷaujos kompozicionālu patvarību, indivīda patvarību. Ja to neizdara, tad jau paliek par fotoobjektīvu, es veidoju savu kompozīciju, mainot redzēto ne uz leju, bet uz augšu. Tie ir mirkḷa momenti, kas ir zelta graudinuu vērti." Katra estampa lapa ir šāds zelta graudiṇš, solis tuvāk tēmai - izpratnei par būtiskāko. Ar katru soli pilnveidojas lineārā izteiksme, tonālais risinājums un kompozīcija. Garajā dzīvē tapušas neskaitāmas lapas, tās grupētas tematiski (cikli "Lirika", "Gauja”, "Druvas", "Karpati” u. c.), bet nav ierobežotas hronologiski, kas tikai pierāda iepriekš teikto - meklējumu ceḷš māksliniekam arvien bijis interesants. Katra estampa lapa ir ne tikai iepriekšējās idejas piepildījums, bet arī nākamās sākums. Tā tas ir, piemēram, ciklā "Lirika", kur pirmās lapas tapušas jau 1948. gadā.

Îpaša tēma mākslinieka daiḷradē ir ekslibri. Jau 1927. gadā, būdams students, viņš ieguva savas kolekcijas pirmos eksemplārus - skolotāja

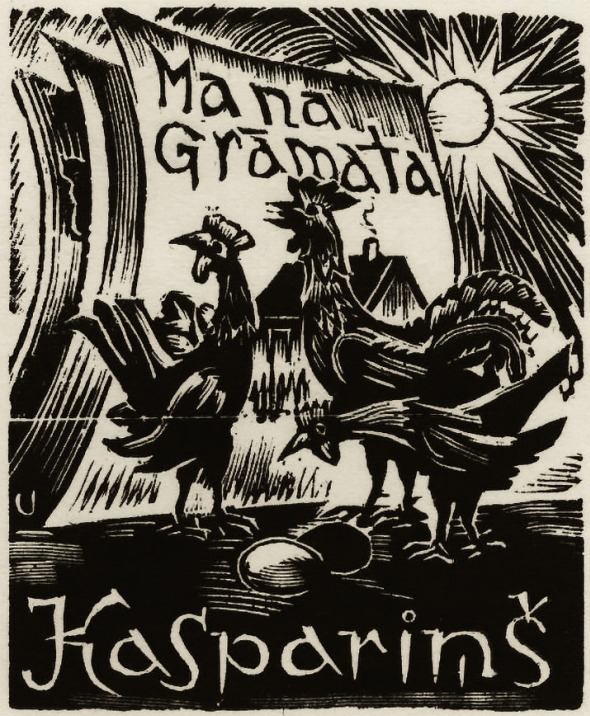

Mana grāmata. Kaspariņš. K. Upītim darināta grāmatzīme. $40 \times 50$ mm. Ksilogrāfija

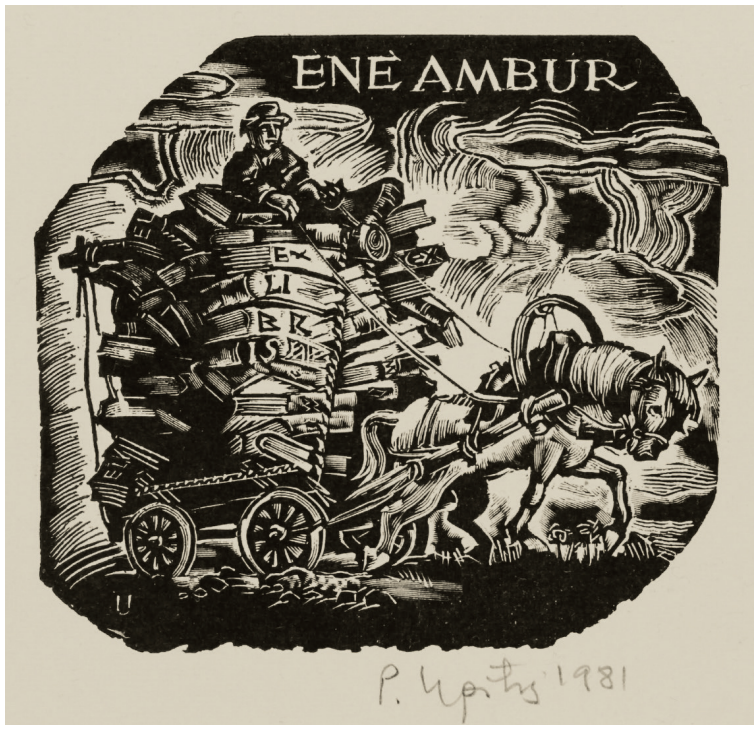

Ene Ambur. $82 \times 85$ mm. 1981. Kokdzelums. Op. 542 
Riharda Zariņa grāmatzīmju novilkumus. Tad top arī pirmie paša veidotie ekslibri. Par daiļrades neatņemamu sastāvdaḷu tie kḷūst, sākot ar 1955. gadu. Jau 1961. gadā Latvijas grafiķis piedalās ar savām grāmatzīmēm izstādē Leipcigā, Vācijā, kas notiek sakarā ar VIII internacionālo grāmatzīmju kongresu. Šajā izstādē Pēterim Upītim ir 24 darbi, Dainim Rožkalnam - 22, bet Zigurdam Zuzem - 15. Tas ir ievērojams sasniegums, iedvesmojoši panākumi, kas mudina regulāri piedalīties šādās miniatūrgrafikas skatēs. Ekslibru māksla ir īpaša, tai nepieciešama l,oti lakoniska, precīza forma un momentāni saprotams, kaut arī bieži simboliski vispārināts saturs. Tāpēc labprātāk tiek darinātas grāmatzīmes sev tuviem un mīliem cilvēkiem. 7

1989. gadā meistars atklāj, ka viņam ir jau 712 grāmatzīmes, un tas jau ir skaitlis, kas ne tikai pārsteidz, tas liecina par mērkstiecīgu neatlaidību, izdomas bagātību, asprātību un unikālu talantu. Pats meistars atceras: “.. īpaši populārs ar savām grāmatzīmēm biju kḷuvis Dānijā. Uzraksta man vienā reizē kāds dāņu inženieris - gribot man pasūtīt grāmatzìmi. Saku, ka neko jau par viņu nezinu, tāpēc nevaru tādu darbu izpildīt. Uz to viņš man atraksta vēstuli, kur sevi precīzi raksturo - esot jūras inženieris,

\section{AVOTI UN LITERATŪRA}

Ivanovs, M. 1961. Pēteris Upitis: grafikas reprodukciju albums. Rīga: Latvijas Valsts izdevniecība.

Silin,š, J. 1993. Latvijas mäksla 1915-1940. III d. Stokholma: Daugava.

Tidomane, G. 1975. Pēteris Upïtis. Rīga: Liesma. viņam esot četrdesmit divi gadi, sieva un divi bērni. Savā grāmatzīmē viņš labprāt redzētu kādu pili, viņam patīkot Andersena pasakas utt. Tā nu es arī piemeklēju motīvu, kur karalisks četrjūgs, velkot pilnu vezumu ar grāmatām, iebrauc pa pils vārtiem... Ne jau vienmēr viss ir tik skaidrs."

Motīvos parādās plašs sižetiskais spektrs dominē ainava, dažādi dabas motīvi, īpaši koki, ziedi, putni un dažādi dzīvnieki, ne mazāk interesantas ir grāmatzīmes, kurās tiek izmantoti klusās dabas elementi, arhitektūra un visu ekslibristu iecienītie Servantesa (Miguel de Cervantes Saavedra; 1547-1616) varoni. Lakoniska tēla radīšanai noder katrs sīkums, nepieciešama vērīga acs, droša roka un liela meistarība. Visās savās grāmatzīmēs Pēteris Upītis apliecina īpašu kompozīcijas meistarību, virtuozu kokgrebuma prasmi un tikai sev vien raksturīgo, dzīvesprieku apliecinošo, veselīgo pasaules uztveri.

\section{Pateicība}

Autore izsaka īpašu paldies Pētera Upīša mazdēlam Kasparam Upītim par iespēju iepazīties ar foto un audio materiāliem par mākslinieku un tiesībām tos izmantot publikācijā.
Upītis, P. 1958. Pirmās latviešu mākslinieciskās grāmatzīmes. No: Latviešu tēlotāja māksla. Rīga: Latvijas Valsts izdevniecība.

Upītis, P. 1960. Jānis Eduards Plēpis. No: Latviešu tēlotāja māksla. Rīga: Latvijas Valsts izdevniecība.

Upītis Pēteris. Latvijas Nacionālā bibliotēka. Reto grāmatu un rokrakstu krājums. 